\title{
SOSIO KULTURAL POLITIK ISLAM KLASIK (Upaya Menafsiri Akar Kemunculan Politik)
}

\author{
Nur Ihsan \\ manasikanaari@yahoo.com
}

\begin{abstract}
Politics are the actions or activities concerned with achieving and using power in a country or society. And The politic has effect to change the best of world, in this chance I will be exploration, what is the ideal politic in the Islam. Because we know the politic gives negatif effect all thaught the reality gives us the best of sistym to the development of the country. So I wanna give the theory about reconstruction Islam of politic, after that we will know what is the ideal politic in our country and we also know the Islam of religion gives us the knowledge how to we take the good condition to our world. So we must know what is the Islam and what is the ideal politic of Islam. And than we must khow the culture of politic in the Islam, so we can wise to all.
\end{abstract}

Keyword: The culture, of politic, in Islam

\begin{abstract}
Abstraksi
Bias perpolitikan terus menggema di area jiwa, hingga wujud politik ini menyentuh batas pada tataran nilai-nilai agama. Akankah politik yang muncul terus menunggangi agama demi kepentingan dunia yang maya? Ataukah agama akan benar-benar menjadi agama yang mampu memberi titik terang terhadap dunia politik, hingga mampu memberi rambu-rambu kenegaraan untuk memberi kemaslahatan rakyatnya. Sebagai seorang cendikia muslim, semestinya menjadi sosok agamawan yang mampu memberi pilihan terhadap fenomena yang berkembang. Selain itu ia juga harus bisa menerima perbedaan yang ada dan meminimalisir karakter ekstrimis yang tidak menyentuh titik humanis, sehingga agama yang sering digaungkan menjadi rahmat di alam semesta raya dapat dirasakan. Artinya, sebuah wajah yang mampu mengayomi semua bentuk fenomena yang terus menggema. Karena agama turun dijadikan sebagai entitas pijakan utama dalam semua ranah permasalahan, baik dalam keluarga, masyarakat dan bahkan sampai bangsa dan negara.
\end{abstract}

Keyword: sosio, kultur, politik, Islam 


\section{A. Pendahuluan}

Tuhan menghendaki Islam sebagai agama dan menjadikan manusia sebagai politikus, Agama sebagai entitas universal, manusia sebagai sosok yang komprehensif, sebagai penggagas dan pelaku atas semua fenomena-fenomena. Jika manusia sebagai subyek (pelaku) dalam menata dan menjalankan tugas-tugas yang ada, maka sudah menjadi keniscayaan membutuhkan perangkat berupa pengangkatan pemimpin dalam sebuah komunitas.

Dalam hal ini pengangkatan pemimpin merupakan tonggak berjalannya politik apalagi yang berkorelasi langsung dengan agama, karena kepemimpinan itu sendiri merupakan dharury (keniscayaan) dalam rangka menjalankan ajaran-ajaran Tuhan. Selain itu eksistensi pemerintahan diperlukan untuk melindungi agama dan pengaturan dunia. Maka dari itu, sudah lazim politik mempunyai peran urgen dalam mengatur dan menata serta mensirkulasikan kebutuhankebutuhan yang ada dalam kenegaraan atau pada aspek kehidupan.

Para pelopor politik islam memandang bahwa Islam itu sendiri merupakan sumber ideologi politik. Bagi mereka Islam bukan hanya sekedar mengatur nilai-nilai peribadatan pada Sang Esa, akan tetapi lebih jauh dari itu, yaitu mengatur seluk beluk interaksi kehidupan umatnya di dunia termasuk masalah politik.

Untuk meminimalisir image negatif, dibutuhkan adanya komunitas-komunitas atau instansi yang moderat untuk mengkampanyekan dirinya sebagai gerakan anti kekerasan dan menjunjung tinggi tata nilai demokrasi. Karena pada masa kedudukan politk, apalagi dalam sistem pemerintahan mendapat liputan dan perhatian yang hebat sekali. Akhirnya dalam dunia sejarah ataupun ilmiah menyatakan bahwa politk Islam merupakan sebuah sistem yang jitu, terpadu dan mempunyai pengaruh besar dalam pembangunan umat, sehingga tidak terlalu berlebihan jika dikatakan bahwa politik adalah pusat kegiatan hidup manusia.

Maka dari itu, dibutuhkan adanya telaah historis terhadap sosio politik Islam, dengan harapan tidak melakukan kesalahan dalam memahami Islam ataupun sistem yang dipakai dalam agama itu. Yang perlu dijadikan titik tekan adalah, analisa kritis atas fenomena yang berkembang dalam masa awal Islam muncul yang telah dipimpin oleh baginda Rasul, karena dari sana kita merunutkan sejarah Islam politik dengan segala tata nilai sosial yang melatar belakanginya. Selain itu, perlu kiranya sebuah konsep sebagai bakal bentuk realisasi epistema yang ada, sehingga akan tergiring pada sakralitas yang dimiliki entitas politik itu sendiri.

\section{Embrio kemunculan Politik Islam}

Sebelum sampai pada embrio kemunculan politik islam, setidaknya kita mengetahui pengertian politik. Dalam dunia praktis, politik selalu berkorelasi dengan masalah mengatur urusan umat baik oleh pemerintah maupun rakyat. Karena terma antara politik dengan negara mempunyai hubungan yang kuat, sehingga, ketika disebut politik akan muncul dibenak sebuah terma negara — dengan kata lain aturan-aturan sebuah negara — keduanya tidak bisa dipisahkan satu sama lain. ${ }^{1}$

1 Mahmud Ismail Muhammad, Dirâsât fi al-’Ulûm al-Siyâsah, tanpa penerbit, t.t, hal. 18 
Adapun politik adalah pengaturan urusan-urusan (kepentingan) umat, baik dalam negeri maupun luar negeri dalam sebuah negara. ${ }^{2}$ Bentuk pengaturan dalam sebuah negara tidak bisa dinafikan adanya seoarang pemimpin (khalifah atau al-Mulk), yang selanjutnya bisa disebut sebagai pemimpin. ${ }^{3}$ Ia bisa dipilih secara demokrasi ataupun aklamasi. Rasulullah saw bersabda: "Adalah Bani Israel, para Nabi selalu mengatur urusan mereka. Setiap Nabi yang meninggal, diganti Nabi berikutnya. Dan sungguh tidak ada lagi Nabi selainku. Tapi akan ada para Khalifah (pengganntiku) yang banyak". ${ }^{4}$

Bisa dikatakan, bahwa esensi politik dalam pandangan Islam adalah sebuah bentuk pengaturan-pengaturan yang didasarkan atas hukum-hukum Islam. Adapun hubungan politik dengan Islam bisa digambarkan bahwa Agama dan kekuasaan (politik) adalah dua saudara yang tidak bisa dipisahkan. Agama adalah pondasi (asas) dan kekuasaan adalah penjaganya. Segala sesuatu yang tidak mempunyai pondasi maka akan runtuh dan segala sesuatu yang tidak ada penjaganya maka akan hilang dan lenyap. Berbeda dengan politik yang diilustrasikan oleh dunia barat, mereka menyatakan bahwa politik adalah sebatas pengaturan kekuasaan, menjadikan kekuasaan menjadi bidikan awal dalam poltik. Akhirnya, jika harapan ini sudah terformulasikan dalam bentuk dogma, maka yang terjadi adalah kekacauan dan perebutan kekuasaan sehingga menafikan urusan-urusan rakyat.

Dari landskap ini, muncul embrio-embrio kemunculan politik Islam yang menjadikan politik sebagai keniscayaan. Ada beberapa pertimbangan sebagai justifikasi statemen tersebut, pertama; adanya syari'at yang memerintahkan kaum muslimin untuk mengurus urusannya berdasarkan hukum-hukum Islam. Allah swt berfirman dalam kitab sucinya "Maka putuskanlah perkara mereka menurut apa yang diturunkan oleh Allah swt dan janganlah kamu mengikuti hawa nafsu mereka dengan meninggalkan kebenaran yang telah datang kepadamu". ${ }^{5}$ Kedua; bahwa Islam memerintahkan untuk tanggap dengan urusan umatnya, sehingga keberlangsungan kehidupan umatnya bisa terjamin. Karena dalam Islam ada kewajiban untuk mengoreksi dan mengkritik penguasa, seperti yang telah difirmankan Allah swt "Dan hendaklah ada diantara kamu segolongan umat yang menyeru kepada kebaikan, menyuruh kepada yang ma'ruf dan mencegah dari yang mungkar. Merekalah orang-orang yang beruntung". ${ }^{6}$

Embrio kemunculan politik Islam diindikasikan dari komunitas keagamaan yang dipimpin Rasulullah saw dengan cita-cita untuk menunjukkan jalan yang benar, membawa kebangkitan

2 Murad Wahbah, Al-Mu’jam al-Falsafiy, Dar al-Tsaqafah al-Jadidah, Kairo, 1979, cet. III, hal. 223

3 Perlu diketahui, ada perbedaan yang signifikan antara al-Khilâfah dan al-Mulk, Al-khilâfah adalah entitas yang mengatur sebuah negara dengan mengikuti aturan-aturan syari'at yang ada dengan mengikuti ajaran-ajaran yang dibawa Rasulullah yaitu ajaran agama Islam. Adapun Al-Mulk identik dengan sebuah kepemimpinan yang mempunyai tujuan mengikuti hawa nafsu dengan mengedepankan kepentingan dunia. Lihat: Ali Abd Al-Raziq,

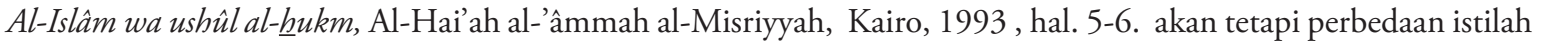
dan definisi, tidak menjadikan elaborasi politik kehilangan identitas, karena keduanya sama-sama berhubungan dengan dunia politik yang merupakan sebagai pelaku (pemimpin) terhadap aturan-aturan kenegaraan.

4 HR Muslim dari Abu Hurairah ra

5 QS. Al-Maidah, 105

6 QS. Ali Imran: 104 
sekaligus untuk menyampaikan risalahnya sebagai utusan. ${ }^{7}$ Kemudian, muncul kelompokkelompok yang bersatu padu untuk menciptakan sebuah komunitas yang teratur, walaupun awal dari pembentukan yang dilakukan melalui person satu ke person lainnya, yaitu melalui kerabat dan teman-teman dekatnya dengan niat ingin menyatukan penduduk makkah mulai Bani Hasyim, Abdul Muthalib sampai kaum Quraisy. ${ }^{8}$

Setelah mereka bersatu dalam bangunan komunitas yang mungkin bisa dikatakan sebagai negara kecil, ${ }^{9}$ mulailah terbentuk sebuah aturan-aturan sebagai eksistensi sosial alami yang merajut pada the development (mencapai titik kemajuan), walaupun saat itu belum tercipta pegawai-pegawai pemerintahan yang mengawasi aktivitas mereka, tapi sudah terbentuk aturanaturan dari hasil musyawarah yang dilakukan pentolan-pentolan dari kabilah mereka. ${ }^{10}$

Setelah beberapa dekade, bisa dikatakan Rasulullah kurang berhasil dalam membangun politiknya di Makkah, akhirnya, Sang Nabi mendapatkan alternatif untuk pindah mencari kabilah-kabilah dan kota-kota lain sebagai tempat obyeknya untuk mengembangkan sayapnya. Akhirnya jengkalan langkahnya menghamparkan pada sebuah tempat yang disebut dengan kota Yatsrib (sekarang kota Madinah), di kota inilah, figur agung yang penuh kharisma ini memperoleh keberhasilan yang gemilang, yaitu keberhasilannya mengumpulkan kabilah-kabilah yang ada dengan mengkonsentrasikan pada epistema-epistema politik secara an sichal. ${ }^{11}$

Dengan pindahnya ke komunitas yang lebih besar, yaitu komunitas yang sudah banyak terkontaminasi dengan ajaran-ajaran Yahudi, Nasrani dan Yunani, tokoh ini mengalami kesulitan-kesulitan untuk menyatukan mereka, sehingga pada awal dekade tidak bisa membentuk sebuah negara yang dipimpin dengan aturan-aturan keagamaan. ${ }^{12}$ Tapi, diranah lain, muncul kekuatan-kekuatan muslimin atas nama agama, sehingga muncul sebuah komunitas yang kuat, dengan jargon bahwa Allah swt sebagai pemimpin negara. Jadi segala sesuatu yang terjadi atas nama kekuasaan maka secara tidak langsung terjadi atas nama Tuhan. ${ }^{13}$ Kekuatan inilah yang menjadikan kelompok islam menjadi kuat, karena mereka merasakan bahwa jiwa mereka sudah menyatu dengan kekuatan Tuhan.

Dalam sistem perpolitikan di masa itu, terbentuk sebuah sistem aherarki, tidak ada perbedaan antara muslim satu dengan muslim lainnya, tidak ada perbedaan antara urusan keduniaan

7 Julius Wellhausen, Târîkh al-Daulah al-'Arabiyyah min Dhuhûr al-Islâm ila Nihâyah al-Daulah al-Umawiyyah, dialih bahasakan oleh, Muhammad Abdulhadi Abu Raidah, Al-Majlis al-A'la litsqâfah, Kairo, 2005, hal. 1

8 Julius Wellhausen, Târîkh al-Daulah al-'Arabiyyah min Dhuhûr al-Islâm ila Nihâyah al-Daulah al-Umawiyyah, hal. 3

9 "negara kecil" untuk tidak mengatakan sebagai negara yang selama ini kita pahami, artinya sebuah negara yang mempunyai undang-undang tertulis, pemimpin dengan segala kekuasaannya, administrasi dan distrik pengadilan. Karena masa itu, aturan-aturan yang ada masih bersifat kesadaran secara personal, tidak ada aturan yang mengikat tindakan-tindakan mereka seperti di zaman modern ini.

10 Julius Wellhausen, Târîkh al-Daulah al-'Arabiyyah min Dhuhûr al-Islâm ila Nihâyah al-Daulah alUmawiyyah, hal. 4

11 Abu Al-A'la Al-Maududi, Al-Khilâfah wa Al-Mulk, Dar Al-Qalam, Kairo, 1978, hal. 37

12 Tidak mampu-nya disini, dipandang dari sudut keberhasilan orang-orang dalam penataan undang-undang yang dilakukan oleh Nasrani ketika menyebarkan agama mereka.

13 Julius Wellhausen, Târîkh al-Daulah al-'Arabiyyah min Dhuhûr al-Islâm ila Nihâyah al-Daulah alUmawiyyah, hal. 8 
ataupun keagamaan. Semua tugas-tugas yang ada merupakan tanggung jawab bersama, seperti problem pengadilan, peperangan ataupun ibadahal. Pada saat itu, masjid mempunyai multi fungsi, seperti menjadi pusat interaksi sosial dan pelatihan militer serta proses ritual keagamaan. ${ }^{14}$

Pada masa setelah hijrahnya—sebelum terjadi perang badar-Rasulullah berhasil menjadikan kota Madinah dalam satu persatuan yang utuhal. ${ }^{15}$ pertumbuhan awal negara arab yang telah didirikan oleh Rasulullah adalah negara kekuasaan imperium yang menganut pada theokrasi-pemerintahan yang terbentuk oleh kaum atau rakyat dengan dasar agama—negara yang terbentuk merupakan sebuah pemerintahan yang membidik secara langsung nilai-nilai politik dan keagamaan. ${ }^{16}$

Diantara faktor-faktor dan perjalanan politik Islam, ada tiga hal yang perlu diperhatikan: pertama, sifat sistem sosial yang didirikan oleh Rasulullah Saw. Kedua, pengakuan akan prinsip kebebasan berpikir untuk segenap individu. Ketiga, penyerahan wewenang kepada umat untuk merinci detail sistem ini, seperti tentang metode manajerialnya, dan penentuan beberapa segi formatnya.

Dengan demikian, sebuah metodologi dapat menyandang dua karakter secara bersamaan. Karena hakikat Islam sendiri merangkum urusan materi dan immateri dan mengurus interaksi manusia dalam kehidupannya di dunia dan akhirat. Bahkan filsafat umumnya merangkum kedua hal itu, dan tidak mengenal pemisahan antara keduanya, kecuali dari segi perbedaan pandangan. Sedangkan kedua hal itu sendiri, menyatu dalam kesatuan yang tunggal secara solid; saling berkelindan sehingga tidak bisa dipisahkan antara satu dengan yang lain.

Pada masa Khulafá Al-Râsyidîn-dilihat dari aturan-aturan politik—tidak jauh beda dengan apa yang dilakukan pada masa Rasulullahal. Walaupun Rasulullah tidak mengangkat langsung seorang pemimpin setelahnya, tapi para muslimin tahu, bahwa pengangkatan pemimpin berdasarkan atas musyawarahal. ${ }^{17}$ Mereka para Khulafá Al-Râsyidîn menciptakan

14 Julius Wellhausen,Târîkh al-Daulah al-Arabiyyah min Dhuhûr al-Islâm ila Nihâyah al-Daulah alUmawiyyah, hal.10

15 Persatuan yang utuh di sini, dimaksudkan pada semua ranah, bukan persatuan yang terjadi ketika masih di Makkah, karena persatuan yang ada di Makkah masih berkutat pada kabilah-kabilah dan nasab. Adapun persatuan di sini merupakan persatuan pada ranah sosial, keyakinan, keagamaan yang sama-sama ingin menegakan agama Tuhan.

16 Julius Wellhausen, Târîkh al-Daulah al-'Arabiyyah min Dhuhîr al-Islâm ila Nihâyah al-Daulah alUmawiyyah, hal.24

17 Seperti yang telah diikrarkan dalam Al-Qur'an untuk tidak membedakan antara muslim satu dengan laiannya. Disisi lain Al-Qur'an juga menganjurkan untuk bermusyawarah dalam satu permasalahan, firman Allah "amruhum Syûra bainahum". Rasulullah juga berpesan kepada para sahabatnya untuk bermusyawarah demi memyelesaikan masalahal. Di sana tidak ada nash Qath'i yang menyatakan adanya pengganti setelah Rasulullah, kecuali Islam hanya menginginkan sebuah aturan yang demokrasi sebuah bentuk pemilihan imam (pemimpin) yang dilakukan oleh umat. Maka dari itu, Rasulullah tidak memberi keputusan dengan jelas siapakah yang menjadi penggantinya. Tapi, seakan-akan Rasulullah menginginkan Abu Bakar sebagai penggantinya dengan dijadikan Abu Bakar sebagai imam shalat, sebuah tugas keagamaan yang besar. Melihat fenomena ini, mereka secara tidak langsung telah mengakui Abu Bakar sebagai pemimpin pengganti Rasulullahal. Perlu dipahami bahwa demokrasi disini bukanlah demokrasi atas terma yang kita pahami dimasa kontemporer ini, karena pemilihan pemimpin waktu itu hanya dilakukan oleh tokoh-tokoh dari mereka sebagai perwakilan yang disebut sebagai "Ahlu al- $\underline{\text { hill }}$ wa al-aqdi" sistem inilah yang dipakai dalam pemilihan khalifah Abu Bakar. 
pemerintahanya melalui jalan musyawarah dengan para muslimin, mereka mempunyai hak penuh untuk mengeluarkan pendapatnya, seperti yang telah diucapkan oleh Umar bin Khatab dalam pidatonya”

"saya tidak mengganggumu kecuali supaya kamu semua mengikuti amanatku dengan semua tanggung jawabku dari perkara-perkara kalian. Saya adalah manusia seperti kalian. Sekarang kalian mempunyai hak, berbedalah denganku bagi orang yang berbeda, dan setujulah-ikutlah-denganku jika cocok. Dan saya tidak menginginkan kalian mengikuti hawa nafsuku..."

Sebuah statemen yang fulgar dan tegas dengan tujuan bisa tercipta sebuah keadilan bagi semua umat sehingga tercipta kemaslahatan yang menyeluruh tanpa ada yang termarginalkan.

Kemudian pada masa Khulafa Al-Râsyidîn, mereka juga membidikkan baitulmal sebagai amanat untuk kemaslahatan muslimin, mereka meng-haram-kan secara mutlak jika mempergunakan baitulmal untuk kepentingan personal. ${ }^{18}$ Inilah yang membedakan antara Khilâfah dengan al-Mulk. Al-mulk (kerajaan) mempergunakan keuangan negara dengan sebebas-bebasnya, sedangkan al-Khlilâfah mempergunakan keuangan negara dengan amanat Sang Khaliq sehingga memberi hak sesuai dengan haknya dan tidak mempergunakannya kecuali kepada yang berhak.

Bila ditelisik lebih dalam, ada sesuatu yang menarik dalam bentuk kepemimpinan Khulafa' Al-Râsyidîn, sebuah bentuk kebebasan yang diberikan kepada kaum muslimin secara terbuka. Ini merupakan bentuk birokrasi yang menjadi keniscayaan pada zaman kontemporer ini. Seperti yang diucapkan oleh Abu Bakar.

"Wahai para manusia, saya adalah pemimpin kalian, tapi saya bukanlah orang yang terbaik dari kalian, jika saya benar maka ikutilah aku, jika saya salah maka ingatkan aku. al-shidq adalah amanah dan al-kidzb (bohong) adalah penghianatan ..."

Sebuah statemen yang jelas dan lugas yang mengandung makna dan harapan untuk menciptakan masyarakat yang terbuka dan sebagai auto kritik bagi dirinya sendiri dan kaumnya secara umum. ${ }^{19}$

Selain itu ada bidikan yang lebih signifikan dalam rancang bangun kepemimpinan mereka, yaitu menghormati undang-undang yang ada, artinya tidak menjadikan dirinya sebagai penguasa tunggal dalam pemerintahan. Para Khalifah dan muslimin tidak ada perbedaan dihadapan undang-undang. Tidak hanya itu, pembentukan pemerintahannya dibentuk dalam bangunan yang egaliter, sehingga adanya bentuk fanatik terhadap golongan, ras dan daerah ternafikan. ${ }^{20}$ Apabila sistem ataupun konsep perundangan Islam menentukan dasar pemerintahan dan politik negara, ia tidak memberi kekuasaan secara mutlak kepada para pemimpin seperti khalifah atau Amir al-Mukminin untuk melakukan sesuka hati. Mereka wajib tunduk kepada hukum dan dasar yang ditetapkan oleh Allah dan Rasul-Nya. Karena para khalifah dan pemimpin yang mengendalikan urusan politik negara pada hakikatnya adalah alat untuk kepentingan agama.

18 Abu Al-A'la Al-Maududi, Al-Khilâfah wa Al-Mulk, hal. 52 
Yang menjadi titik tekan pada bahasan ini adalah terciptanya ruh demokrasi dalam pemerintahan Masa Khulafá' Al-Râsyidîn, sehingga tercipta kebebasan yang sempurna untuk menuangkan ide-ide yang ada. Sebagai wujud demokrasi, Para khalifah langsung terjun dalam komunitas ablu al-Syûra untuk membahas problematika yang berkembang dan mencari solusi bersama atas permaslahan yang dihadapi. Pada fenomena seperti ini, semua permasalahan diserahkan kepada ahlu al-hill wa al-aqdi sebagai penanggung jawab, dengan menafikan keberpihakan pada satu kelompok dan menciptakan keputusan yang sebenarnya. ${ }^{21}$

Setelah tiga puluh tahun, masa Khulafa' Al-Râsyidîn berganti ke al-mulk, ruh demokrasi agak kabur diterpa angin kekuasaan. Sehingga nilai aturan pemerintahan mengalami kritik yang tajam, karena sistem pemerintahannya sudah menafikan adanya musyawarah melainkan mengedepankan kekuatan. ${ }^{22}$

Karakterisasi politik yang terjadi dalam fenomena-fenomena masa Khulafa' Al-Râsyidîn belum bisa dikatakan sebagai bentuk pemerintahan politik yang hakiki, akan tetapi sebuah bentuk aturan politik sebagai pengganti aturan yang dibawa Rasulullahal. Artinya pemerintahan yang dibangun belum sampai pada tataran undang-undang negara secara resmi, menciptakan keamanan, menjaga batas-batas negara dan menjalankan administrasi, akan tetapi masih dalam rancang bangun tahap koordinasi atas nilai-nilai ajaran agama, seperti halnya yang telah dilakukan Rasulullahal. Maka dari itu politik terus melaju dan berkembang menyesuaikan kondisi yang ada.

\section{Rancang Bangun Politik Islam}

Eksistensi epistema tidak bisa lepas dari unsur yang menjustifikasinya, dari justifikasi itu terbangun sebuah tatanan untuk menciptakan sebuah metodologi yang memperkuat bagan itu sendiri. Kurang lebihnya ada dua hal yang selalu diperbincangkan dalam konsep politik islam, karena memang entitas ini yang memegang titik sentral dalam berjalannya negara yaitu, siapa yang harus dipilih menjadi kepala negara (pemimpin) dan siapa yang berhak memilihnya. ${ }^{23}$ Dalam wacana poltik Islam klasik menyebutkan sejumlah persyaratan yang ideal dan beragam dalam menata kenegaraan lebih-lebih dalam wacana kepemimpinan, selain itu juga me-nyenggol pada tatanan para punggawa pemerintahan yang disusul dengan atribut-atribut keuangan negara serta kekuatan militer sebagai pengayom masyarakat secara umum.

Kepemimpinan merupakan obyek terurgen dalam dunia sosial, lebih-lebih dalam tatanan negara. karena entitas inilah yang memegang tongkat estafet kepemimpinan Rasulullah untuk menjaga agama dan dunia, selain itu kedudukan khalifah atas umatnya sama halnya kedudukan Rasulullah bagi kaum mukminin, sehingga sang pemimpin mempunyai kekuatan dan kekuasaan yang harus diaplikasikan dengan harapan mampu menjalankan aturan-aturan keagamaan. ${ }^{24}$

21 Abu Al-A'la Al-Maududi, Al-Khilâfah wa Al-Mulk, hal. 60

22 Mohammad Abid Al-Jabiri, Al-'Aql al-Siyâsi al-Arabi, Dar Al-Baidha', Maroko, 2000. cet. V. hal. 189

23 Al-Mawardi, Al-A hkầm Al-Sulthâniyyah wa Al-Wilâyât Al-Dîniyyah, Maktabah Al-Tawfiqiyyah, Kairo, t.t, hal. 17

24 Julius Wellhausen,Târîkh al-Daulah al-'Arabiyyah min Dhuhûr al-Islâm ila Nihâyah al-Daulah alUmawiyyah, hal. 24 
maka dari itu pengangkatan seorang figur pemimpin adalah sebuah keniscayaan (wajib) ${ }^{25}$. Baik itu dilihat dari ranah syari'at ataupun logika.

Sementara itu, Al-Juwaini memberi syarat bahwa calon pemimpin harus punya kapabelitas tinggi, mampu berijtihad sekaligus mampu menerapkan nilai-nilai zuhud, wara', 'ilmu. ${ }^{26}$ Dalam ranah kepemimpinan, Sang imam (pemimpin) ditetapkan sesuai kaedah-kaedah keagamaan, karena ia merupakan subyek yang mengatur kemaslahatan umat secara menyeluruh, kemudian entitas ini dikaitkan pada analisa-analisa keagamaan dengan tetap melihat hukum-hukum yang ada, seperti mempunyai kepekaan terhadap fenomena-fenomena sosial sebagai upaya untuk membangkitkan politik umat. Jika seorang pemimpin mampu merealisasikan ini, secara tidak langsung ia telah memenuhi hak-haknya kepada Tuhan-nya dan mahluk-mahluk lainnya. ${ }^{27}$

Lebih jelasnya, untuk menciptakan pemimpin yang ideal harus memenuhi syarat-syarat tertentu. Syarat yang harus dipenuhi oleh pemimpin adalah seluruh anggota badan sempurna (kuat dan mampu melaksanakan tugas-tugas yang ada, mempunyai karakter bisa cepat memahami atas fenomena yang terjadi, kuat hafalannya (mampu menyimpan memori apa yang dilihat, didengar dan apa yang telah ditemukan dalam benaknya), mempunyai kecerdasan yang tinggi, sehingga ketika menemukan sebuah kejadian, ia mampu bersikap, suka dengan pendidikan, bisa menghormati entitas lain dan berkarakter adil, ${ }^{28}$ sehingga jika semua karakter ini bisa dimiliki, maka mampu mengais kesuksesan dunia politiknya yang kemudian kesuksesan itupun akan dirasakan masyarakat secara umum, akhirnya bisa menciptakan kemaslahatan yang menyeluruhal. Sebenarnya, Landskap ini mengacu pada epistema live society, karena realita inilah yang menjadi titik tolak meraih keberhasilan.

Di sudut lain, ada bangunan persyaratan yang juga harus dipenuhi oleh orang-orang yang bakal memilih, seperti mempunyai karakterisasi adil diberbagai ranah, mempunyai kapabilitas pemikiran untuk memilih calon pemimpin, yaitu calon pemimpin yang berhak dan layak untuk menjabat sebagai pemimpin.

Sekarang, bagaimana ketika sang pemimpin sudah keluar dari jalur karakterisasi kepemimpinanya? Seperti sifat keadilannya mulai luntur (fasik, yang notabene hanya mengikuti hawa nafsunya), mengalami gangguan pada organ tubuh, seperti kerusakan pada panca inderanya-hilang akalnya_, sebagian anggota tubuh hilang sehingga untuk melakukan tugas sebagai pemimpin terhambat dan atau sang pemimpin mulai melakukan kemaksiatan yaitu sebuah tindakan-tindakan yang keluar dari jalur agama. maka dengan fenomena ini

25 Statemen ini berbeda dengan Al-Mawardi. Al-Mawardi masih enggan untuk menyatakan bahwa pengangkatan Imam itu wajib, figur ini masih mempertimbangkan dan mencari celah-celah rasionalitas dan syari'at. Bisa dikatakan bahwa tokoh ini masih patut untuk dikatakan sebagai intelektual moderat. Akan tetapi, bisa disimpulkan dalam persoalan ketegasan, tokoh ini belum bisa sampai pada level itu. Lihat: Al-Mawardi, $A l-$ Ahkam Al-Sulthaniyyah, bandingkan dengan Al-Juwaini, Ghiyâts al-Umam fì Qiyâs al-Zhulmi.

26 Abu al-Mảali Al-Juwaini, Ghiyâts al-Umam fî Qiyâs al-Zhulmi, ditahkik, Dr. Fu’ad Abdul. Mun'im dan Musthafa Hilmi, Dar al-Dakwah al-Iskandariyyah, 1979, hal.13-14

27 Adil Tsabit, Al-Fikr Al-Siyâsiy Al-Islâmiy, Dar Al-Jami;ah Al-Jadidah, Kairo, 2002, hal. 27

28 Abu Nasr Al-Farabi, Kitâb Arâ’ ahl al-Madînah al-Fâdhilah, Dar Al-Masyriq, Beirut, cet.IV, 1986, hal. $127-128$ 
legalitas kepemimpinannya dipertanyakan kembali. ${ }^{29}$ Maka, tidak salah jika Al-Juwaini memaparkan sistem politiknya dengan penyikapan yang jitu, yaitu problematika pengangkatan kepemimpinan dan problematika ketika pemimpin itu hilang atau tiada, kemudian menyusul dengan pemikirannya untuk menyikapi ketika penegak-penegak syari'at Musnahal. Dengan harapan yang tidak muluk-muluk, yaitu menginginkan adanya negara yang damai dan aman serta terhindar dari sifat-sifat kedhaliman. ${ }^{30}$

Dari beberapa statemen di atas, bisa dilihat adanya hubungan yang berkelindan atas hak-hak dan kewajiban antara sang pemimpin dengan rakyatnya. Dengan tetap menjunjung tinggi sifat keadilan diantara mereka, seperti sang hakim melakukan hukuman atas tindakan narapidana dalam satu kasus. Dalam kasus ini sang hakim secara tidak langsung telah menjunjung agama Allah yang tidak menafikan kemaslahatan umat. Ketika sang pemimpin sudah memenuhi kriteria yang ada, maka rakyat-pun harus menaati semua perintah yang diputuskan, dengan ketentuan tidak berupa tindakan maksiat kepada Sang Khaliq. ${ }^{31}$

Salah satu sub tema yang tidak kalah urgen adalah konsep memerangi para pembangkangpembangkang negara (Bughât), ketika aturan sudah dijunjung bersama, sementara ada kelompok Islam lain yang melakukan pengasingan diri dan apatis terhadap undang-undang yang ada, dan akhirnya menciptakan mazhab baru, maka sang imam (pemimpin) diperbolehkan untuk memberi hukuman kepada mereka dengan ketentuan tidak sampai pada tataran menghilangkan nyawa. Batasan hukum inipun jika para pembangkang itu mengasingkan diri dengan tidak menafikan ketaatannya kepada pemimpin. Tapi, jika pembangkangan itu sudah sampai pada tataran perlawanan kepada pemerintah, maka pemerintah harus bersikap untuk menumpas mereka.

Bila ditelisik lebih dalam, bahwa sebuah tata aturan pemerintahan akan mengalami gesekangesekan yang tidak bisa dihindarkan adanya kontra, seperti bentuk revolusi atau munculnya fitnah-fitnahal. Sebenarnya ini adalah bentuk auto kritik pada penguasa selama tindakan itu tidak sampai pada pengangkatan senjata. ${ }^{32}$ Yang perlu digaris bawahi adalah, bagaimana seorang pemimpin mampu bersikap arif dalam menyikapi fenomena itu. Maka diharapkan bagi sang pemimpin untuk tidak selalu mengunakan kekerasan kecuali sudah sampai pada indikasi ingin meruntuhkan pemerintahan.

Konsep-konsep politik selalu berkembang menyesuaikan zaman, perlu dipahami bahwa rancang bangun ini terdapat aturan-aturan dalam pengangkatan pemimpin pada dunia politik, karena figur inilah yang sarat dengan pelaku dan sebagai penanggung jawab atas hukum-hukum yang ada, dengan menyertakan dengungan bahwa rakyat harus mematuhi titah-titah sang penguasa, selama tidak melanggar nilai-nilai keagamaan. ${ }^{33}$

29 Abu Nasr Al-Farabi, Kitâb Arẩ ahl al-Madînah al-Fâdhilah, hal. 28-29. bandingkan dengan Al-Mawardi, Al-Ahkâm Al-Sulthâniyyah wa Al-Wilâyât Al-Diniyyah, hal. 14-15

30 Abu Al-Juwaini, Ghiyâts al-Umam fì Qiyâs al-Zhulmi, hal.12-13

31 Abu Al-Juwaini, Ghiyâts al-Umam fì Qiyâs al-Zhulmi, hal. 30

32 Mohammad Thaha Badawi, Syar'iyyah al-Tsaurah fi al-Falsafah al-Siyâsiyyah, majalah Kulliayatul $\underline{\text { Huqu} q}$ Jamiah Iskandariyyah, edisi I dan II, 1954, hal. 160

33 Adil Tsabit, Al-Fikr Al-Siyâsiy Al-Islâmiy, hal. 32 
Merujuk pada statemen Al-Mawardi, bahwa tugas pemimpin adalah menjaga agama dan merealisasikan keadilan antar umat manusia, seperti hukum pidana, menjaga keamanan negara dan mengatur ketertiban umum, menciptakan benteng sebagai upaya melindungi negara dari musuh, menjalankan menejemen atau administrasi kenegaraan, sehingga, masyarakat bisa menjalankan aktivitasnya dengan aman.

Melihat atribut-atribut kenegaraan yang sedemikian komplek, tidak menafikan elemenelemen itu makin banyak dan makin meluas, seperti yang kita pahami bahwa terma politik itu sendiri selalu berkembang dan selalu menyesuaikan masa serta kebutuhan umat. ${ }^{34}$

Aturan hukum pada sebuah negara mebutuhkan dasar-dasar ilmu politik yang kuat, seperti perpolitikan negara, administrasi, keuangan negara, ilmu peperangan dan distrik pengadilan. Adapun korelasinya dengan dunia perpolitikan, tidak bisa dinafikan adanya faktor pendukung seperti bantuan sang wazir (mentri) dan beberapa perangkat pemerintahan. Adapun tentang administrasi difokuskan pada aturan-aturan kenegaraan seperti, majlis pajak bumi, majlis bagian surat menyurat, majlis arsip, majlis militer dan lain sebagainya. Adapun tentang keuangan negara, berfokus pembagian ghanimah, Fai', zakat, hasil pajak bumi, undang-undang pembagian harta dan lain sebagainya. Adapun tentang peperangan, membidik pada pengaturan strategi perang dan segala peralatannya. Adapun tentang pengadilan, mengarah pada sikap adil terhadap narapidana yang ada dengan sebisa mungkin memberi komposisi sama pada setiap obyek. ${ }^{35}$

Untuk memperjelas konsep-konsep politik secara utuh, ${ }^{36}$ perlu kiranya memperjelas elemen-elemen kenegaraan sebagai berikut:

\section{B. Sistem Politik ${ }^{37}$}

Dalam dunia perpolitikan, seorang pemimpin mempunyai andil besar. Maka, pengangkatan seorang khalifah merupakan sebuah kebutuhan. Al-Khilâfah adalah bentuk kepemimpinan yang digunakan dalam masa setelah Rasulullah, adapun setelah itu menggunakan terma al-Mulk dengan tidak menafikan tugas-tugasnya sebagai pemimpin secara umum. Al-Khilâfah identik dengan tugas-tugasnya yang berfokus pada ruang keagamaan dan keduniaan sebagai ganti sang

34 Sulaiman Mohammad Al- Thamawi, Al-Sulthâth al-Tsalâts fì al-dasâtîr al-Arabiyyah al-Mu'âsharah wa fì al-Fkr al-Siyâsiy al-Islâmiy, Dar al-Fikr al-Arabiy, cet. VI, 2996, hal. 398

35 Hasan Ibrahim Hasan, Tarîkh al-Islâm al-Siyâsi wa al-Dîn wa al-Tsaqâfi wa al-IjtimẩI, Maktabah alNahdhah al-Misriyyah, Kairo, cet. V, 1959, hal.427

36 Bila kita menelaah buku-buku yang ada, kita akan menemukan metode-metode yang berbeda pada setiap penggagas, selain itu, metode penyampaiannya juga sangat beragam, maka, kecerdasan pembanca adalah sebuah keniscayaan untuk memetakan metode mereka. Karena untuk bisa memetakan membutuhkan kontemplasi panjang. Sehingga untuk mencapai kesempurnaan untuk menciptakan negara ideal adalah hal yang nisfulmustahil (untuk tidak mengatakan utopis). Baca: Ahkam Al-Sulthaniyyah milik Al-Mawardi. Kitâb Arầ ahl al-Madînah alFadhilah dan Kitâb al-Jam'I baina rày al-Hukmain milik Al-Farabi. Tarîkh al-Islâm al-Siyâsi wa al-Dîn wa al-Tsaqâfi wa al-Ijtimẩi milik Hasan Ibrahim Hasan.

37 Kata "politik" yang ditulis disini adalah sistem politik dalam negara, kata ini skopnya lebih kecil, karena politik disini hanya difokuskan pada hal negara yang terbatas, dari pada politik yang di bahas dalam makalah ini. Jadi diharapkan pembaca tidak terkecoh dengan penggunaan kata-kata ini, sehingga bisa memahami maksud penulis 
Nabi. ${ }^{38}$ Bisa dikatakan, bahwa ini merupakan sebuah bentuk tanggung jawab secara keseluruhan atas nilai-nilai syari'at dalam kemaslahatan dunia akhirat. Karena segala urusan dunia kembali pada nilai-nilai aturan syari'at yang nota bene berkelindan dengan nila-nilai ukhrawi. Dari sini, memungkinkan untuk mengatakann bahwa sang Khalifah adalah pemegang syari'at untuk menjaga keeksisan ajaran-ajaran agama serta perpolitikan dunia. ${ }^{39}$

Elemen yang mengikuti Al-Khilâfah adalah Al-Wuzarâ.. Al-Wuzarâ merupakan Terma yang sudah digunakan sebelum Islam muncul, masa Persia dan bani Israel. Istilah ini identik sebagai entitas seorang pembantu (karyawan) pada pemimpin utama—sebagai contoh Abu Bakar pada masa Rasulullah di sebut sebagai wazîrunnabiy — tidak menafikan sebagai entitasnya yang asli, sebenarnya sang Wazir (menteri) mempunyai tugas berat untuk tanggung jawabnya atas realita masyarakat yang terjadi, karena sirkulasi fenomena sosial bertitik tolak atas ide-ide yang ia gulirkan. Bila tugas-tugas kenegaraan hanya dibebankan pada sang khalifah sangat tidak mungkin sang pemimpin mampu melaksanakannya, karena secara tabi'at, manusia adalah entitas yang lemah yang pastinya membutuhkan entitas lain untuk membantunya. ${ }^{40}$ Wajar bila sang Musa sebagai nabi minta kepada Tuhan-nya untuk menciptakan entitas lain (Nabi Harun) supaya membantunya sekaligus meringankan tugas-tugasnya. Firman Allah " wajal lî wazîran min ahli harûna akbi ushdud bihi azrî wasyrikhu fì amrî."’ıl

Atribut lain yang mendukung sistem perpolitikan adalah Al-Kitâbahal. Al-Kitâbah merupakan unsur terpokok dalam sistem politik kenegaraan, bisa dikatakan bagian ini menjadi sub sentral dalam sirkulasi kebutuhan-kebutuhan negara. Karena dari entitas ini tercipta sebuah acuan-acuan untuk menciptakan sebuah negara yang tertib dan berperadaban. Wajar bila zaman arab dulu dikatakan sebagai masa jahiliyyah karena tidak punya administrasi dalam pengaturan negara. Pada setiap pemerintahan pasti akan mempunyai juru tulis sebagai pencatat sejarah dan kebutuhan-kebutuhan negara. Pada masa Abu Bakar, Usman bin Affan diangkat sebagai juru ketiknya. Pada masa Umar bin Khatab menjadi khalifah, beliau mengangkat Ali bin Abi Thalib, Zaid bin Tsabit, Muawiyah bin Abi Sufyan sebagai juru tulis kenegaraan. Pengangkatan ini terbukti dengan keberhasilannya mampu menyatukan mushaf Al-qur'an, selain itu juga sebagai juru tulis ketika sang pemimpin ingin mengirimkan surat kepada instansi lain, serperti yang telah dilakukan Rasulullah sendiri. ${ }^{42}$

Ketika Al-Khilâfah beralih ke bumi Muawiyah, al-kitâbah menjadi lebih penting dalam pemerintahan mereka, karena mereka merasakan bahwa sistem administrasi dalam pemerintahan mampu mempengaruhi kemaslahatan negara, seperti penulisan data surat-surat, pajak tanah, ketentaraan (militer) dan pengadilan negara.

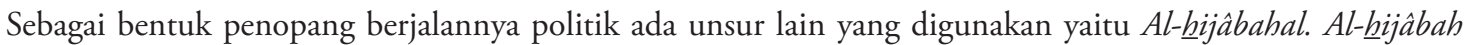
adalah Karyawan-karyawan dalam majlis-majlis besar dalam negara Islam. Untuk mengakumulasikan elemenelemen itu, perlu kiranya adanya instansi sebagai penyambung. Pada masa Khulafá Al-Râshidîn, karyawankaryawan diberi kebebasan penuh untuk keluar masuk dalam urusan negara, selain itu mereka mengetahui seluk beluk luar dalam urusan-urusan negara hatta internal khalifah itu sendiri, sehingga jika sang $\underline{h a j j i b ~ i n i ~ m e m p u n y a i ~}$ i'tikad negatif, maka negara tersebut cepat atau lambat akan mengalami kehancuran. Ini terbukti dengan fenomena orang-orang Khawarij pada masa Ali bin Abi Thalib dan Muawiyahal. Setelah terjadi pergantian khalifah ke Bani Umayyah, entitas ini di hilangkan karena membahayakan eksistensi dan entitas negara itu sendiri.

Dalam sebuah komunitas, tidak bisa dihindarkan adanya entitas yang lebih tinggi, seperti halnya dalam anggota badan, ada anggota badan yang lebih tinggi kegunaannya dibandingkan dengan anggota lainnya, seperti kedudukan hati diantara anggota lainnya, jika anggota satu ini hilang maka bangunan tubuh akan lumpuh total, walaupun tidak menafikan keberadaan anggota lain. Begitu juga kedudukan seorang pemimpin negara, dia adalah entitas yang tertinggi dibandingkan dengan anggota lain, ${ }^{43}$ walaupun tidak menafikan kedudukan seoarang wuzarâ, al-hijâbah, al-dawâwîn dan al-idâriyyahal. Kongklusinya, adanya sebuah penciptaan kemaslahatan yang dirasakan oleh semua khalayak, karena duka cita, pasang-surut atau maju-mundurnya sebuah negara dirasakan

38 Hasan Ibrahim Hasan, Tarîkh al-Islâm al-Siyâsi wa al-Dîn wa al-Tsaqâfi wa al-IjtimẩI, hal. 428

39 Ibn Khaldun, Muqaddimah Ibn Khaldun, tanpa penerbit, Mesir, 1331 H, hal.166

40 Hasan Ibrahim Hasan, Tarîkh al-Islâm al-Siyâsi wa al-Dîn wa al-Tsaqâfi wa al-Ijtimẩ, hal. 440

41 Q.S, Thaha, ayat 29-31

42 Hasan Ibrahim Hasan, Tarîkh al-Islâm al-Siyâsi wa al-Dîn wa al-Tsaqâfi wa al-IjtimầI, hal.440

43 Abu Nasr Al-Farabi, Kitâb Arẩ abl al-Madînah al-Fâdhilah, hal. 120 
bersama, sehingga tidak menafikan kewajiban bagi pemerintah untuk bertanggung jawab dan menaggung segala problematika yang didera oleh rakyatnya. ${ }^{44}$

\section{Sistem Administrasi}

Bidang ini sudah muncul semenjak masa awal Islam, diera Persia dan Roma. Sub ini mempunyai bangunan penting dalam sebuah negara, karena administrasi mempunyai peran signifikan dalam perjalanan suatu negara. Salah satu yang perlu diperjelas adalah administrasi mempunyai korelasi dengan majlis-majlis atau dewan-dewan (Al-Dawâwîn), Al-Dawâwîn adalah sebuah lembaga yang berkaitan dengan hak-hak penguasa, misalkan tentang aktivitasaktivitasnya dan sirkulasi keuangan serta berhubungan dengan bidang ketentaraan sekaligus tugas-tugasnya. ${ }^{45}$

Korelasi selanjutnya adalah Al-imârah 'ala al-buldân, pemerintahan pada masa jahiliyyah mempunyai karakterisasi demokrasi, akan tetapi sistem demokrasi memakai cara pengumpulan tokoh-tokoh masyarakat-disebut sebagai ahl al hill wal aqdi- bermusyawarah untuk mengambil kata sepakat. Pada zaman Rasulullah, tidak hanya berjalan pada tataran nilai-nilai keagamaan saja, tapi juga menyentuh dalam tataran perpolitikan, dengan sebuah justifikasi bahwa Rasul kala itu menjadi pemimpin perang, sekaligus menjadi hakim, selain itu Sang Rasul juga membagi harta-harta hasil dari peperangan. ${ }^{46}$ Artinya figur ini mempunyai beberapa jabatan sekaligus, satu sisi menjadi pemimpin keagamaan satu sisi lagi dalam ranah politik.

Untuk mengatur sebuah wilayah, perlu kiranya ada ketua perwakilan, sehingga untuk mengkoordinir negara-negara bagian menjadi mudahal. Seperti pada masa Umar bin Khatab, wilayah Makkah ditugaskan kepada Nafik bin Al-Harits Al-Khaza’i sedangkan Pada masa Utsman bin Affan ditugaskan kepada Abdullah bin Al-Khudhari. Adapun wilayah Tha'if Pada zaman Umar ditugaskan kepada Sufyan bin Abdullah Al-Tsaqfi sedangkan Pada masa Utsman ditugaskan kepada Al-Qasim bin Rabi’ah Al-Tsaqfi. Adapun Mesir pada masa Umar bin Khathab ditugaskan kepada Umar bin Ash, Sedangkan pada masa Utsman ditugaskan kepada Abdullah bin Sa'ad.

Terkait dengan majlis-majlis bagian administrasi adalah al-barîd, bidang ini berfokus untuk menyampaikan berita dengan cepat atas perkembangan kondisi yang ada. Sub ini tambah berkembang setelah masa Muawiyah bin Abu Sufyan, kemudian di teruskan Abdul Malik bin Marwan. Melihat manfaat yang bisa diambil, Al-barîd menjadi perangkat yang diberi porsi lebih dalam suatu negara untuk mengendalikan dunia politik kenegaraan. ${ }^{47}$

Selain itu, adalah Al-Syurthah, sebuah entitas yang bertanggung jawab atas keamanan dan ketertiban negara. sub ini mempunyai peran tangung jawab untuk menjaga sang khalifah atau waliyyul amri, dilain sisi juga menjaga aturan-aturan yang ada dengan mencegah timbulnya instansi-instansi yang merongrong pemerintahal. Maka dari itu bidang ini merupakan pondasi

44 Sayyid Aliyawah, Usûl ;Ilm al-Siyâsah, Maktabah Jami'ah Helwan, Kairo, 1986, hal. 79

45 Hasan Ibrahim Hasan, Tarîkh al-Islâm al-Siyâsi wa al-Dîn wa al-Tsaqâfi wa al-Ijtimâ'I, hal. 440

46 Hasan Ibrahim Hasan, Tarîkh al-Islâm al-Siyâsi wa al-Dîn wa al-Tsaqâfi wa al-IjtimầI, hal. 452

47 Hasan Ibrahim Hasan, Tarîkh al-Islâm al-Siyâsi wa al-Dîn wa al-Tsaqâfi wa al-IjtimẩI, hal. 459 
untuk memperkuat tata nilai kekuatan keamanan atas negara. ${ }^{48}$

\section{Sistem Keuangan}

Dalam sebuah negara, sirkulasi keuangan merupakan salah satu bagian nafas hidup berjalannya program dan politik serta tugas kenegaraan lainnya, maka dari itu sirkulasi keuangan mempunyai peran penting dalam berdirinya sebuah negara. Sub ini digunakan untuk memberi balancing dalam urusan keluar masuknya keuangan di sebuah negara. Aktivitas ini sudah berlangsung semenjak berdirinya negara Islam dengan sebutan baitul mal yang difokuskan kepada kemaslahatan umat. Adapun pada masa kontemporer ini, nama ini identik dengan dewan keuangan. ${ }^{49}$

Dalam aturan badan keuangan mempunyai tugas yaitu untuk menjalani berbagai sirkulasi dalam bentuk pengeluaran dan pendapatan. adapun pada ranah pendapatan adalah, Al-Kharâj (pajak tanah), pajak tanah ini di tekankan pada bumi kekuasaan yang diduduki, biasanya hasilnya digunakan untuk kemaslahatan umum. Selanjutnya, sebagai bentuk uang pemasukan negara adalah Al-'Asyûr, yaitu pajak sepersepuluh dari harta dagangan orang-orang kafir yang bermukim di negara Islam. Walaupun ada salah satu ulama yang menyarankan hanya menarik setengah dari sepersepuluh, tapi jika kemudian kemaslahatannya dan kebutuhan naik, pajak itu bisa dinaikkan..$^{50}$

Aturan ini sebenarnya sudah ada pada masa Umar bin Khattab, satu ketika Abu Musa AlAsy'ari menuliskan surat kepada Umar, bahwa para pedagang muslim ketika berada didaerah orang-orang kafir (yang tidak terdapat sama sekali orang muslim disana) mereka ditarik pajak sepersepuluhal. Kemudian sahabat Umar-pun mengambil keputusan untuk memungut pajak orang-orang kafir dengan sepersepuluh seperti halnya mereka mengambil pajak sepersepuluh dari orang-orang muslim. ${ }^{51}$

Sisi lain dari sirkulasi keuangan negara adalah zakat (sedekah), zakat dan sedekah adalah satu terma yang berfokus pada pembersihan harta. Sub ini diisyaratkan pada pencucian harta sehingga mampu menjauhkan diri dari sifat hasut kepada orang fakir miskin. Konsep ini adalah sebuah bentuk untuk menjaga dan menjalankan sirkulasi keuangan negara, selain zakat adalah jizyah (barang rampasan), fai ${ }^{52}$ dan ghanimah ${ }^{53}$.

\section{E. Sistem Peperangan}

Untuk menciptakan negara yang kuat perlu adanya pondasi dan bangunan-bangunan penjaga. Maka dari itu, dunia kemiliteran mempunyai kedudukan yang signifikan. Kemiliteran ini mulai muncul pada masa Umar bin Khatab. Khalifah ini menciptakan sebuah komunitas khusus kemiliteran dengan segala kebutuhannya. Kemudian setelah kelompok ini sudah

48 Hasan Ibrahim Hasan, Tarîkh al-Islâm al-Siyâsi wa al-Dîn wa al-Tsaqâfi wa al-IjtimầI, hal. 459

49 Hasan Ibrahim Hasan, Tarîkh al-Islâm al-Siyâsi wa al-Dîn wa al-Tsaqâfi wa al-IjtimầI hal. 461

50 Hasan Ibrahim Hasan, Tarîkh al-Islâm al-Siyâsi wa al-Dîn wa al-Tsaqâfi wa al-IjtimầI hal. 467

51 Hasan Ibrahim Hasan, Tarîkh al-Islâm al-Siyâsi wa al-Dîn wa al-Tsaqâfi wa al-IjtimầI hal. 468

52 Fai' adalah harta benda rampasan dari orang-orang musyrik tanpa melalui peperangan.

53 Ghanimah adalah harta benda rampasan dari orang-orang musyrik dengan melalui peperangan. 
terkoordinir dengan rapi, muncul dewan bagian kemiliteran yang bertugas menjaga ketertiban umum. melihat entitas ini berkembang pesat dan menjadi kebutuhan negara, metode ini diteruskan pada masa bani Umayyah kemudian disusul pada masa Abdul Malik bin Marwan. Bukti dari keberhasilannya adalah ekspansi-ekspansi yang dilakukan oleh Umar pada beberapa negara yaitu, Irak, Syam, Palestina, Mesir dan lainnya. ${ }^{54}$

Sistem lain yang dipakai dalam peperangan adalah metode peperangan yang ada di daerah lautan, awal mulanya metode ini tidak diizini oleh para khalifah Islam seperti Umar bin Khattab. menurut Ibn Khaldun, ketidaksetujuan wujudnya program ini karena para pasukan tidak bisa menguasai cara perang di laut atau kurang lihai menggunakannya. Kemudian pada masa Utsman bin Affan sistem peperangan ini digalakkan dengan menciptakan lautan sebagai jalan perang. Orang yang diutus pertama adalah Abdullah bin Qais, dengan kebehasilannya yang gemilang. Setelah itu, diteruskan pada zaman Muawiyah dengan menciptakan kapal laut sampai berjumlah 1700 kapal. ${ }^{55}$

\section{F. Sistem Pengadilan}

Pada masa awal kemunculan Islam, Rasulullah adalah hakim atas permasalahan yang muncul, seperti ketika ada perselisihan antara muhajirin, Ahli Madinah dan orang-orang Yahudi. Setelah sepeninggal Sang Nabi, predikat hakim di ambil oleh Umar bin Khattab setelah mendapat amanat dari khalifah pertama Abu Bakar As-Siddiq. ${ }^{56}$ Ketika Islam mulai berkembang dan mengalami akulturasi dengan agama lain, dunia sosial menunturkan untuk menciptakan aturan-aturan Islami yang lebih kuat dan relevan dengan zaman yang ia naungi dengan tidak menafikan keberadaan Al-Qur'an dan Al-Sunahal. Maka dari itu perlu adanya undang-undang tertulis yang disepakati oleh khalayak dan yang tentunya bersifat maslahah bagi semua ranah kehidupan.

Ada entitas lain yang perlu kirannya di sebut disini, entitas itu adalah al-hisbah (sang pengawas) untuk memantau perjalanan pemerintahan. Adapun tugas dari instansi ini adalah amar makruf nahi munkar, menjaga etika yang ada dan menjunjung tinggi nilai-nilai hukum syari'at. Selain itu, entitas ini mempunyai hak untuk menghukum bagi orang-orang yang membangkang. Di ranah lain, ada instansi yang lebih tinggi, kelompok ini digunakan ketika pihak keadilan tidak bisa mengambil keputusan hukum. Maka dari itu persyaratan kelompok ini adalah seorang tokoh yang berpengetahuan luas, mempunyai kharisma tinggi dan wara'.

Inilah beberapa konsep politik untuk mengatur sebuah negara, baik itu urusan internal ataupun eksternal. Untuk menjadikan sebuah negara yang punya peradaban maju, tertib, aman dan disegani pihak luar, maka dibutuhkan konsep politik yang matang.

\section{G. Penutup}

Setelah mengetahui embrio kemunculan politik Islam, perjalanan dan konsep-konsep

54 Hasan Ibrahim Hasan, Tarîkh al-Islâm al-Siyâsi wa al-Dîn wa al-Tsaqâfi wa al-IjtimầI hal. 477

55 Hasan Ibrahim Hasan, Tarîkh al-Islâm al-Siyâsi wa al-Dîn wa al-Tsaqâfi wa al-IjtimẩI hal. 483

56 Hasan Ibrahim Hasan, Tarîkh al-Islâm al-Siyâsi wa al-Dîn wa al-Tsaqâfi wa al-Ijtimâ'I hal. 486 
yang dipakai, selanjutnya akan dibahas bagaimana kiprah politik itu sendiri dan bagaimana sistem yang digunakan politik untuk tetap eksis disemua ranahal. Sebenarnya ketika kita menyentuh permasalahan mengenai agama atau negara maka sudah semestinya akan melibatkan permasalahan politik. Karena unsur ini adalah entitas yang menunggangi berjalannya agama ataupun negara.

Agama merupakan elemen terkuat untuk menciptakan masyarakat bersatu padu, sehingga tidak jarang agama dijadikan sebagai alat untuk menyatukan umat, walaupun tekadang atas nama agama terjadi persengketaan bahkan peperangan, karena agama sendiri mempunyai potensi untuk menggerakkan "massa" dengan apapun bentuknya, baik dalam nuansa positif maupun negatif, tergantung politik model apa yang menunggangi agama. Karena antara agama dengan politik mempunyai hubungan kuat. Maka dari itu, awal kemunculan Islam dengan wajah keramahan, dan cinta dengan persatuan serta perdamaian merupakan politik untuk menggait para kabilah kala itu. Sehingga dengan mengaitkan urusan dunia dengan agama merupakan metode jitu yang sudah teruji.

Selanjutnya untuk menyatakan Islam politik, masih ada golongan yang enggan menyetujui. Padahal paham kesatuan agama dan negara (al-din wa al-Daulah) atau kesatuan agama dan politk adalah sebuah keniscayaan, karena agama tanpa politik maka akan rapuhal. Karena agama sendiri membutuhkan penjagaan yang kuat dengan politik sebagai bodyguard-nya. Karena tujuan politik sendiri adalah menata kekuatan masyarakat dan membantu menyelesaikan problematika yang dialami kelompok-kelompok masyarakat. ${ }^{57}$

Perlu dicerna bahwa setiap sesuatu yang mempunyai korelasi dengan akidah dan ibadah adalah agama, maka ia bisa dikatakan sebagai politik Islam dalam Ibadahal. dan setiap perkara yang berhubungan dengan etika dan pendidikan adalah agama, maka boleh dikatakan politik etika dan pendidikan. Setiap perkara yang berhubungan dengan muamalah adalah agama, maka bisa disebut sebagai politik muamalat dan seterusnya. Dari sisi ini, keduanya mempunyai hubungan erat dalam ranah tata negara atapun tata keagamaan, ia saling membutuhkan satu sama lain dan saling menjustifikasi dengan menciptakan satu tujuan demi kemaslahatan umat.

Maka, bisa dikatakan Sebuah entitas keilmuan akan mengalami gradualisasi pada semua ranah, maka dari itu entitas tersebut selalu bergesekan dengan alam yang ia naungi, sehingga menemukan wujudnya untuk meneruskan cita-citanya. Dari landskap ini ilmu politik tidak bisa lari dari pasang-surut sebuah analisa. Karena di sana terjadi pergolakan sistem, ideologi, metodologi, sudut pandang dan situasi kondisi.

Fakta tentang karakterisasi Islam sudah jelas, perjalanan dan fakta-fakta sejarah yang telah terlewati memberi sebuah kongklusi bahwa Islam bukan hanya sekedar dakwah agama, tapi Islam adalah sebuah pengaturan masyarakat sosial dengan berbagai ranah yang ada dengan tidak menafikan ajaran-ajaran ukhrawi.

Maksudnya, Islam bukan hanya sekadar keyakinan atau hubungan rohani antara individu

57 Mulham Qurban, Al-Wâqi'iyyah al-Siyâsiyyah, Al-Mu'assasah al-Jami’iyyah liddirasat wan Nasyr wattuzi”, Beirut, 1981, hal. 47 
98 Nur Ihsan

dengan Rabb-nya, akan tetapi lebih dari itu. Sehingga ajaran Islam tetap memiliki hubungan dengan urusan-urusan yang kita namakan sebagai urusan materi dalam kehidupan dunia ini. Di antara urusan-urusannya adalah: masalah-masalah peperangan dan harta, dan yang paling utama adalah masalah politik.

Adapun dalam tataran bangunan politik, sama sekali bukan sekedar bentuk agama yang terpisah dari dan terletak dibawah kekuasaan pemerintahan duniawi. Akan tetapi bisa berjalan beriringan untuk menuju kemaslahatan bersama, baik dunia ataupun akhirat. Perlu dipertegas, bahwa awal pendirian negara (terformulasikan politik) merupakan salah satu tujuan diutusnya Rasul oleh Tuhan. Dengan demikian segala fenomena yang terjadi di Madinah hanyalah berupa jama'ah Islam yang telah mengalami transformasi dari fase teoritis ke fase praksis.

\section{Bibilografi}

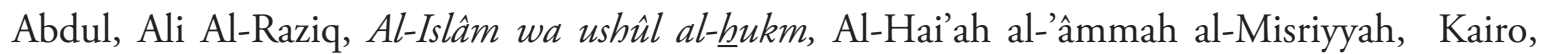
1993

Abid, Mohammad Al-Jabiri, Al-'Aql al-Siyâsi al-Arabi, Dar Al-Baidha', Maroko, 2000. cet. V.

Abu Al-A’la Al-Maududi, Al-Khilâfah wa Al-Mulk, Dar Al-Qalam, Kairo, 1978

Aliyawah, Sayyid, Usûl ;Ilm al-Siyâsah, Maktabah Jami’ah Helwan, Kairo, 1986

Ibrahim, Hasan Hasan, Tarîkh al-Islâm al-Siyâsi wa al-Dîn wa al-Tsaqâfi wa al-IjtimầI, Maktabah al-Nahdhah al-Misriyyah, Kairo, cet. V, 1959

Ismail, Mahmud Muhammad, Dirâsât fi al-'Ulûm al-Siyâsah, tanpa penerbit, t.t, hal. 18

Khaldun, Ibnu, Muqaddimah Ibn Khaldun, tanpa penerbit, Mesir, $1331 \mathrm{H}$

Al-Mawardi, Al-A $\underline{h} k \hat{a} m$ Al-Sulthâniyyah wa Al-Wilâyât Al-Dîniyyah, Maktabah Al-Tawfiqiyyah, Kairo, t.t,

al-Ma'ali, Abu Al-Juwaini, Ghiyâts al-Umam fî Qiyâs al-Zhulmi, ditahkik, Dr. Fu'ad Abdul. Mun’im dan Musthafa Hilmi, Dar al-Dakwah al-Iskandariyyah, 1979

Mohammad, Sulaiman Al- Thamawi, Al-Sulthâth al-Tsalâts fî̀ al-dasâtîr al-Arabiyyah alMu'âsharah wa fî al-Fkr al-Siyâsiy al-Islâmiy, Dar al-Fikr al-Arabiy, cet. VI, 2996

Nasr, Abu Al-Farabi, Kitâb Arầ ahl al-Madînah al-Fâdhilah, Dar Al-Masyriq, Beirut, cet.IV, 1986 ,

Thaha, Mohammad Badawi, Syar'iyyah al-Tsaurah fî al-Falsafah al-Siyâsiyyah, majalah Kulliayatul huqûq Jami'ah Iskandariyyah, edisi, I dan II, 1954

Tsabit, Adil, Al-Fikr Al-Siyâsiy Al-Islâmiy, Dar Al-Jami;ah Al-Jadidah, Kairo, 2002, hal. 27 
Qurban, Mulham, Al-Wâqi'iyyah al-Siyâsiyyah, Al-Mu'assasah al-Jami'iyyah liddirasat wan Nasyr wattuzi”, Beirut, 1981

Wahbah, Murad, Al-Mujam al-Falsafiy, Dar al-Tsaqafah al-Jadidah, Kairo, 1979, cet. III

Wellhausen, Julius, Târîkh al-Daulah al-'Arabiyyah min Dhuhûr al-Islâm ila Nihâyah al-Daulah al-Umawiyyah, dialih bahasakan oleh, Muhammad Abdulhadi Abu Raidah, AlMajlis al-A'la litsqâfah, Kairo, 2005. 
